
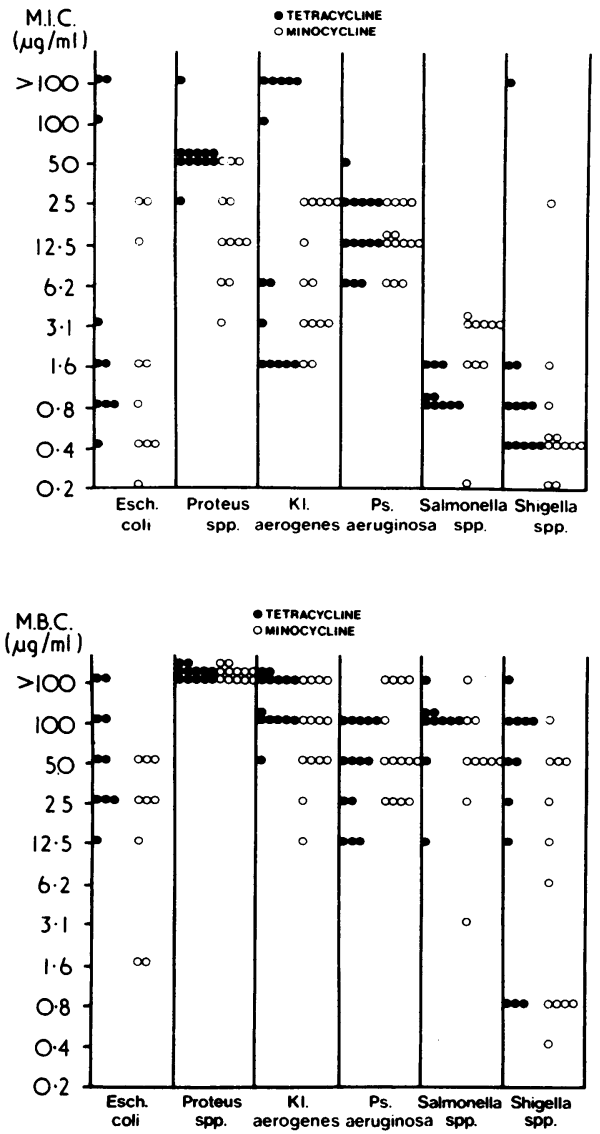

results it should be remembered that, according to the independent investigators quoted by the manufacturers, minocycline in standard dosage (an initial oral dose of $200 \mathrm{mg}$ followed by $100 \mathrm{mg}$ twice daily) produces serum concentrations of only 1-3 $\mu \mathrm{g} / \mathrm{ml},^{1-4}$ that ordinary doses of tetracycline (for example, $250 \mathrm{mg}$ 6-hourly) will produce peak serum levels in the order of 2-4 $\mu \mathrm{g} /$ $\mathrm{ml}^{5}$ and that with Proteus species neither antibiotic was bactericidal or likely to be therapeutically effective. With the other Gram-negative bacteria the activity of the two antibiotics appeared to be similar.-I am, etc.,

N. A. Simmons Department of Clinical Bacteriology and Virology, Guy's Hospital,

1 Heine, P., Thesis, 1969, University of Zurich

2 Kanazawa, Y., and Kuramata, T., Ұapanese łournal of Antibiotics, $1969,22,417$.

Kawamori, Y., and Nishizawa, N., fapanese fournal of Antibiotics, 1969, 22, 426.

4 Okubo, H., Fujimoto, Y., Okamoto, Y., and Tsukada,' J., Fapanese Fournal of Antibiotics, $1969,22,430$

Garrod, L. P., Lambert, H. P., and O'Grady, F., in Antibiotic and Chemotherapy, ed. L. P., Edinburgh and London, Churchill Livingstone, 1973.

\section{Prevention of Accidental Hypothermia}

SIR,-In the timely and excellent review of accidental hypathermia by Professor A. N. Exton-Smith (22 December, p. 727) he recommends among preventive measures the recognition of old people at risk and advice on suitable clothing and bedding. The health department of the London Borough of Wandsworth have issued home nurses and health visitors with low-reading clinical thermometers and room thermometers for the assessment of old people at risk and of the current trial of duvets for the prevention of hypothermia. The duvets (continental quilts) being used are the type filled with Terylene P3 and are regarded as an alternative measure to blankets or lowwattage electric blankets.

The duvet is cheap, has a good insulation weight ratio, saves much effort in bedmaking, and as well as being a bed cover can be used to wrap up o.d people during the day. In these days of uncertain fue supplies it is pertinent that the duvet needs no power source. As a practical community project some members of an old people's club have made duvets from "home-sew" kits and have thus saved on the cost as well as having the satisfaction of doing something active. A loan from the local Age Concern Committee made it possible for the kits to be bought wholesale, reducing the cost still further, and as the loan is repaid it will be available for other clubs. Many old people strongly resist charity, but this type of aid is acceptable since they have to participate actively and what they receive is a genuine bargain.-I am, etc.,

London S.W.15

M. A. Church

\section{Acute Pancreatitis and Diabetic \\ Ketoacidosis in Hypothermia}

SIR,-We wonder whether Dr. D. Maclean and his colleagues (29 December, p. 757) are justified in including diabetic ketoacidosis in the title of their paper since at no point is there any reference to the presence of ketones in breath, blood, or urine. The diagnosis presumably rested on evidence of acidosis, and the possibility of lactic acidosis should at least be considered in a metabolic disturbance of this degree of severity.

It has been shown repeatedly that elevation of the blood amylase level may occur in subjects with uncontrolled diabetes without any evidence of pancreatic disease. ${ }^{1-3}$ We are, etc.

John Malins

Diabetic Clinic,

General Hospital

C. H. WALSH

1 Belfiore, F., and

2 Knight A Hillialis Knight, A. H., Wrilliams, D. N., Ellis, G., and
Goldberg, D. M., British Medical fournal, 1973,

3,128 .
3 Finn, R., and Cope, S., Diabetes, 1963, 12, 141.

\section{Rupture of Abdominal Wound after Laparoscopy}

SIR,-Complete rupture of the abdominal wound after laparoscopy occurs very infrequently. ${ }^{12}$ I wish to report such a case.

A woman aged 32 years who had five children was admitted for sterilization. She was an un healthy, thin, weary woman who smoked heavily. Under endotracheal anaesthesia a 2-cm infraumbilical incision was made and 51 . of carbon dioxide gas instilled through a Verres needle. The trocar (11 mm diameter) passed very easily direct into the abdominal cavity. Laparoscopy was performed, followed by tubal coagulation with Palmer coagulation forceps inserted through a small cannula in the right iliac fossa. The gas was totally evacuated and the wounds closed with fine monofilament nylon sutures. The patient, who was discharged 24 hours later, was readmitted on the fourth day with omentum protruding from the umbilical wound. Under general anaesthesia the wound was enlarged, part of the omentum excised, and the remainder returned to the abdomen. The wound was closed with no. 1 nylon sutures inserted through all layers of the abdominal wall and had healed soundly by the 10th day, when the sutures were removed. The patient defaulted from the follow-up clinic.

Poor abdominal muscles, a thin linea alba, and postoperative coughing may have contributed to the wound dehiscence, but the failure to use a " $Z$ tract" when inserting the trocar was all-important. Normally the trocar should be inserted through the umbilical wound and then pushed inferiorly and subcutaneously for at least $3 \mathrm{~cm}$ before being thrust into the abdominal cavity. This " $Z$ tract" acts as a valve and reduces the leakage of gas. What is equally important is that this technique minimizes the chance of rupture of the wound, which should now be numbered among the serious postoperative complications of laparoscopy.-I am, etc.,

Women's Hospital,

Alan M. SMITH

Wolverhampton

1 Bishop, H. L and Halpin, T. F., American Fournal of Obstetrics and Gynecology, 1973, 116,

2 Duignam, N. M., Jordan, J. A., Coughlan, B. M. and Logan-Edwards, R., fournal of Obstetrics and Gynaecology of the British Commonwealth, 1972, 79, 1016 .

\section{W.M.A. and Racial Discrimination}

SIR,-Ghana's original motion at the W.M.A. Assembly (Supplement, 3 November, p. 26) referred to discrimination on the grounds of "colour" only. The motion finally carried refers to "religion, race, colour, or politics in any form." Neither in your report (3 November) nor in subsequent correspondence (8 December, pp. 614 and 615) is it made absolutely clear that South Africa voted for and Ghana against the final motion, which "vehemently condemns" discrimination on all these grounds. In voting for the motion South Africa was merely reaffirming what the Medical Association of South Africa affirmed before a Government Commission two years before the W.M.A. was founded. ${ }^{1}$ Even then it was ahead of the W.M.A. at Munich, as it included sex among the excluded grounds. Strangely - why? - the W.M.A. motion went on to instruct and empower the W.M.A. Council "to investigate as carefully and as fully as possible" only "the issue of colour discrimination."

May I express the hope that the Council will be much more careful in their investigations and conclusions than many of those who have written about medicine in South Africa in the medical as well as in the lay press, and that, in particular, they will be careful to discriminate between the actions and attitudes of doctors in South Africa and those of laymen and the Government?-I am, etc.,

Surbiton, Surrey

G. W. GALE

1 South Africa, Report of National Health Service Town Government Printer, 1944.

\section{Pregnancy after Hysterotomy}

SIR,-Drs. W. M. Clow and A. C. Crompton (10 February, p. 321) reported a substantial risk of uterine rupture in pregnancies in women who had previously had a preg- 